\title{
Auditory Cortical Temporal Processing and Hemispheric Asymmetry Revealed by NI Dipole Source Activity in Adult Cochlear Implant Users
}

\author{
Jihyun Lee ${ }^{1 *}$, Ji-Hye Han ${ }^{1 *}$, and Hyo-Jeong Lee ${ }^{1,2} \mathbb{D}$ \\ ${ }^{1}$ Laboratory of Brain \& Cognitive Sciences for Convergence Medicine, Hallym University College of Medicine, Anyang; and \\ ${ }^{2}$ Department of Otorhinolaryngology, Hallym University College of Medicine, Anyang, Korea
}

\section{$\mathrm{N} 1$ 활동성으로 나타난 성인 인공와우 사용자의 청각정보 처리 능력과 반구상 비대칭}

이지현 ${ }^{*} \cdot$ 한지혜 $^{1 *} \cdot$ 이효정 ${ }^{1,2}$

한림대학교 의과대학 뇌인지융합의학연구소 ${ }^{1}$, 한림대학교 의과대학 이비인후과학교실 ${ }^{2}$

\footnotetext{
Received November 26, 2018

Revised January 25, 2019

Accepted March 8, 2019

Address for correspondence

Hyo-Jeong Lee, MD, PhD

Laboratory of Brain \& Cognitive

Sciences for Convergence Medicine,

Department of Otorhinolaryngology,

Hallym University

College of Medicine,

291 Simin-daero, Dongan-gu,

Anyang 14054, Korea

Tel $+82-31-380-9410$

Fax +82-31-386-3860

E-mail hyojlee@hallym.or.kr

*These authors contributed equaly to this work.
}

Background and Objectives Cochlear implant (CI) changes the way that sound inputs are processed in the brain, possibly causing brain reorganization. Given that the pattern and degree of reorganization are known to be related to speech perception skill, information regarding hemispheric asymmetry can be used to predict behavioral performances in CI users. The current study investigated the hemispheric asymmetry of N1 dipole cortical activity in response to the temporally varied speech sounds and its relationship to speech perception abilities in adult CI users.

Subjects and Method The cortical activity was recorded from 64 scalp electrodes in $10 \mathrm{CI}$ users and 11 normal-hearing controls. Speech stimuli were synthesized consonant-vowels, the /ba/-/pa/ continuum that ranged from 0 to $50 \mathrm{~ms}$ with a 6 -step voice onset time (VOT). N1 dipole amplitudes, latencies, and locations were analyzed as a function of VOT and the direction of implantation. Also investigated was the relationship between N1 dipole lateralization and speech perception.

Results For the N1 dipole location, significant location differences between CI and normal hearing groups were seen at $40 \mathrm{~ms}$ VOT in the anterior-posterior direction. For hemispheric asymmetry, the N1 dipole activity in good CI performers was higher in the auditory cortex contralateral to the stimulated ear, while poor CI performers showed greater ipsilateral activity. In addition, a lateralization index at $20 \mathrm{~ms}$ VOT showed significant correlation with the / $\mathrm{ba} /-/ \mathrm{pa} /$ consonant perception scores in noise.

Conclusion The results suggest that the hemispheric asymmetry of N1 dipole activity in response to stimuli of temporally varied speech has a substantial clinical value, and that this can be used to estimate CI speech perception.

$$
\text { Korean J Otorhinolaryngol-Head Neck Surg 2019;62(7):385-94 }
$$

Key Words Cochlear implant · Dipole source analysis · Hemispheric asymmetry · Voice onset time.

This is an Open Access article distributed under the terms of the Creative Commons Attribution Non-Commercial License (https:/creativecommons.org/licenses/by-nc/4.0) which permits unrestricted non-commercial use, distribution, and reproduction in any medium, provided the original work is properly cited. 


\section{서 론}

인공와우(cochlear implant)는 고심도 감각신경성 난청자 를 대상으로 청각(hearing sensation)을 되살릴 수 있는 유 일한 방법으로 현재까지 전 세계적으로 많은 청각장애인들 에게 적용되어 왔다. 인공와우의 사용은 단순히 말초적인 청 감각을 되살릴 뿐만 아니라, 새로운 청각 신호의 유입을 통 한 대뇌피질 가소성(cortical plasticity)을 유도하여 대뇌피질 재조직화를 유발하는 것으로 알려져 있다.) 특히, 인공와우 사용으로 유발된 대뇌피질 재조직화에 의해 뇌 활동성이 왼 쪽 혹은 오른쪽으로 치우치는 현상을 의미하는 반구상 비대 칭(hemispheric asymmetry) 또한 바뀐다는 연구 결과가 발 표된바 있다. ${ }^{2)}$ 정상 청력인의 경우 소리 자극을 한쪽 귀에 제 시하였을 경우 자극음을 제시한 방향과 동일한 반구, 즉 동 측(ipsilateral) 보다 대측(contralateral) 반구의 청각 피질에 서 더 큰 반응성을 보이는 것으로 보고되어 왔다. ${ }^{3)}$ 반면 인공 와우 사용자는 인공와우 착용 방향, 인공와우 이식 시기, 인 공와우 이식 순서, 그리고 청각 손실의 기간과 같은 요인에 따라 반구상 비대칭의 패턴이 달라지는 것으로 나타났다. ${ }^{4}$

인공와우 사용자의 대뇌피질 재조직화를 살펴본 선행연구 들에 의하면 인공와우 이식 시기와 양측 인공와우 사용 여 부가 반구상 비대칭의 변화에 영향을 미친다고 보고하였다. ${ }^{4)}$ 이러한 반구상 비대칭의 변화는 특히 인공와우를 이식한 아 동 혹은 청소년에게 두드러지게 나타났다. P1 쌍극자 신호원 을 이용하여 대뇌피질 재조직화를 측정한 한 연구에 따르면, 한쪽 인공와우를 이식한 후 단기간 내에 다른 쪽에도 인공 와우를 이식하거나, 양측 인공와우를 동시에 이식한 아동들 은 정상적인 수준의 대측 활동성을 보인 반면, 오랜 기간 동 안 편측 인공와우를 착용한 아동에서는 대측 대뇌피질 활동 성이 비정상적으로 높게 나타났고, 이러한 패턴이 강하게 나 타날수록 말지각력 점수는 낮게 나타났다. ${ }^{4)}$ 최근 연구에서 는 오랜 기간 편측 인공와우를 착용한 청소년에게 다른 한쪽 귀에도 인공와우를 이식한 후 대뇌 활동성을 측정하였다. 연 구 결과, 인공와우를 착용해왔던 귀에 청각적 자극을 제시하 였을 때 정상인에 비해 횔씬 큰 대측 활동성이 나타났으나, 새로 인공와우를 이식한 귀에 청각 자극을 제시하였을 때에 는 대뇌피질 활동성이 비정상적으로 크고 뇌 전체에 퍼진 양 상으로 나타났다. 또한 이러한 뇌 활동성은 단어 지각력과 유의미한 상관관계를 나타내었다.5) 따라서 인공와우 사용자 의 반구성 비대칭 패턴의 변화는 인공와우 사용으로 인한 대뇌피질의 재조직화를 반영한다고 볼 수 있다.

기능적 자기공명영상(functional magnetic resonance image)을 이용하여 인공와우를 이식한 성인의 대뇌피질 재
조직화를 관찰한 선행연구에 따르면, 말소리 인지와 연관된 음운 축약(phonological process)을 처리할 때 상후장골극 측두 이랑(posterior superior temporal gyrus)과 연상회 (supramarginal gyrus)를 포함한 오른쪽 측두엽 부위가 왼 쪽 반구의 측두엽에 비해 더욱 활성화된 것으로 나타났다.) ${ }^{18} \mathrm{~F}$-fluorodeoxyglucose positron emission tomography $\left({ }^{18} \mathrm{~F}-\right.$ FDG PET)을 이용한 대뇌 연결성 연구에서도 일차 청각 피 질(primary auditory cortex)의 대사율이 인공와우 착용 귀 의 동측 반구에서 기능적 연결성이 더 높게 나타났으며, 이러 한 반구성 비대칭 현상은 인공와우를 착용한 성인에 비해 아 동에서 더 두드러지게 관찰되었다.) 하지만 인공와우를 착용 한 성인을 대상으로 반구상 비대칭을 관찰한 선행연구들은 비대칭 패턴에 대해 상이한 결과들을 보고하였는데, 그 원인 중 하나는 여러 연구에서 tone burst 혹은 클릭음 같은 단순 음을 사용하여 대뇌 활동성을 측정하였기 때문으로 보인다. 실제로 클릭 같은, 자연음과는 동떨어진 소리들을 이용하여 대뇌피질 활동을 측정하는 경우 결과의 일관성이 떨어지는 것으로 보고되고 있다.) 따라서 실제 말소리와 유사한 자연 스러운 소리를 이용하여 인공와우 사용자를 대상으로 한 대 뇌피질의 재조직화에 대한 연구가 더욱 필요한 실정이다. 일 부 연구는 인공와우 사용자 사이에 보이는 말지각 능력의 차 이가 그들의 신경 가소성 속도와 정도 차이에 기인한다고 주 장하였다. ${ }^{8)}$ 예를 들어, 인공와우 사용자에게 시각 자극을 제 시하였을 때 청각 중추가 시각 자극을 처리하는 데 관여하는 교차 감각 재조직화(cross-modal reorganization)가 일어나 는 현상이 확인되었으며, 이러한 재조직화의 정도는 인공와 우 사용자의 말지각력과 상관관계가 있다고 보고하였다.,10) 따라서 청각 손실과 인공와우 사용에 따른 대뇌 재조직화의 변화를 측정하고, 객관적으로 측정한 대뇌 활동성과 주관적 인 행동적 수행력과의 상관관계를 밝히는 것은 과학적, 그리 고 임상적으로 중요하다고 볼 수 있다.

본 연구에서는 뇌전도(electroencephalography) 기술을 이용하여 N1 쌍극자 신호원을 측정하여 시간적 변화를 포함 한 말소리에 따른 대뇌 활동성의 변화와 반구상 비대칭을 알 아보고자 한다. N1을 선택한 이유는 청각 사건 관련 전위 (auditory event-related potential, AEP)를 구성하는 여러 하위 성분 중 N1이 청각 관련 정보에 가장 민감하게 반응하 는 성분으로 알려져 있기 때문이다. ${ }^{11,12)}$ 또한, 본 연구에서는 6 가지 단계의 음성개시시간(voice onset time, VOT)이 포함 된 말소리를 소리 자극으로 사용하였다. 정상 청력인을 대상 으로 VOT의 길이 변화에 따른 $\mathrm{N} 1$ 의 변화를 관찰하였을 때, $\mathrm{VOT}$ 가 증가할수록 $\mathrm{N} 1$ 의 진폭이 작아졌으며, ${ }^{13)}$ 긴 $\mathrm{VOT}$ 를 가진 청각 자극을 사용한 경우 두 개의 N1 정점(double peak) 
이 나타났다. ${ }^{14)}$ 인공와우 사용자의 N1과 말지각력을 조사한 연구에서는 VOT의 길이에 따른 N1의 변화와 말지각 능력 간의 유의미한 상관관계를 확인하였다. ${ }^{15)}$ 또한 인공와우 사 용자를 대상으로 VOT에 따른 범주 지각과 N1의 상관관계 를 알아본 최근 선행연구에서는 말지각력이 낮을수록 범주 지각(categorical perception)이 나타나는 VOT가 늦어지며, 이는 N1 진폭과 관련이 있다고 밝힌바 있다. ${ }^{16)}$

따라서, 본 연구에서는 VOT 변화에 따른 N1 쌍극자 진폭 및 잠재기의 변화를 알아보고, 반구상 비대칭을 수치적으로 나타낼 수 있는 N1 쌍극자의 편재화 지수(lateralization in$\mathrm{dex}$ )를 계산하여 대뇌 편측화를 측정하였다. 특히, 범주 지 각과 N1 진폭의 변화를 측정한 선행연구에서/바/와 /파/를 구분하는 범주 지각의 경계가 약 $20 \mathrm{~ms}$ VOT에서 나타난다 고 밝힌바 있으므로, ${ }^{16)}$ 본 연구에서는 $20 \mathrm{~ms}$ 의 편재화 지수 를 이용하여 인공와우 사용자들의 말지각력과 반구상 비대 칭의 상관관계를 조사하였다.

\section{대상 및 방법}

\section{연구 대상}

본 연구를 위해 영어를 모국어로 하는 인공와우 사용자 10명(남 4명, 연령 범위: 32 74세, 평균: 49.6세)과 정상 청력 을 가진 성인 11명(남 4명, 연령 범위: 20 42세, 평균: 31세) 이 참여하였으며, 모든 피험자는 오른손잡이였다. 인공와우 사용자들은 신시내티 아동 병원의 임상시험윤리위원회 프로 토콜(IRB No. 2013-0105)에 따라 모집되었으며, 인공와우 이식 후 1 년 이 지났으며, 하루에 적어도 8 시간 인공와우를 꾸준히 착용하였다고 보고한 성인을 대상으로 하였다. 10명 의 인공와우 사용자 중 2 명의 난청 발생시기는 언어 습득 이 전, 8 명은 언어 습득 이후인 성인으로, 수술 전 청력은 대상
자 모두 고도 이상이었다. 인공와우를 착용한 피험자 모두 양쪽 귀의 말지각력을 실시하여 수행력이 더 좋은 한쪽 귀에 만 인공와우를 착용한 상태로 본 실험에 참가하였다. 인공와 우 대상자의 연령, 성별, 인공와우 착용 귀, 착용 기간, 인공 와우 세부정보는 Table 1에, 그리고 말지각력 검사 결과에 대한 정보는 Table 2에 제시하였다. 또한, 인공와우 사용자군 은 모음과 자음 인지 검사(Vowel and Consonant Recognition Test)와 소음 하 말지각(Speech Perception In Noise, $\mathrm{SPIN}$ ) 검사를 수행하여 우수(good)군과 저조(poor)군의 두 그룹으로 구별하였다. SPIN 검사는 http://www.tigerspeech.com에 무료 배포된 검사 도구를 이용하였으며, 총 50 개의 문항을 듣고 따라 말하는 검사로서, 단어와 문장 수 준의 지각력을 측정할 수 있다. 자음 검사는 총 16 개의 "a/C/ a” 구조로 총 400회 제시되었으며, 모음은 “h/V/d”의 구조로 10 개의 단모음 및 2 개의 이중 모음 비율로 총 300 개의 모음 을 제시하였다. 총 10 명의 인공와우 피험자 중 40점 이하의 총점(composite score)을 보인 4명의 사용자들은 저조 사용 자군으로, 50점 이상의 총점을 가진 6명의 사용자들은 우수 사용자군으로 분류되었다.

건청인 11 명은 모두 양이 순음청력검사 결과 $250 \mathrm{~Hz}$ 부터 $8000 \mathrm{~Hz}$ 까지 옥타브 단위 주파수에서 $15 \mathrm{~dB} \mathrm{HL}$ 이하의 정 상 청력을 보였다. 모든 참여자는 동의서 서명 후 실험에 참 여하였다.

\section{자극음}

자극음은 하스킨스 연구소(Haskins laboratories)가 개발 한 Abramson/Lisker VOT 자극음에서 수정된 6단계의 /바/ - /파/ VOT 연결체로, 이 6개의 음절은 각각 $0 \mathrm{~ms}$ 에서부터 $50 \mathrm{~ms}$ 까지 $10 \mathrm{~ms}$ 의 간격으로 넓어지는 6개의 VOT를 포함 한다(http://www.haskins.yale.edu/featured/demo-lisk-

Table 1. Demographics of the adult $\mathrm{Cl}$ recipients

\begin{tabular}{ccccccccccc}
\hline $\begin{array}{c}\text { Cl } \\
\text { User (years) }\end{array}$ & Gender & Clside & $\begin{array}{c}\text { Stimulated } \\
\text { ear }\end{array}$ & $\begin{array}{c}\text { Duration of } \\
\text { deafness } \\
\text { (year) }\end{array}$ & $\begin{array}{c}\text { Cl use } \\
\text { (year) }\end{array}$ & $\begin{array}{c}\text { Device/ } \\
\text { Processor }\end{array}$ & $\begin{array}{c}\text { Processing } \\
\text { strategy }\end{array}$ & $\begin{array}{c}\text { Type of } \\
\text { deafness }\end{array}$ & $\begin{array}{c}\text { Etiology of } \\
\text { hearing loss }\end{array}$ \\
\hline 1 & 32 & F & Bilateral & Left & 20 & 9 & Nucleus/Cl24RE & ACE & Postlingual & Hereditary \\
2 & 34 & F & Bilateral & Right & 33 & 12 & Nucleus/Esprint & SPEAK & Prelingual & Congenital \\
3 & 37 & F & Bilateral & Right & 37 & 11 & Nucleus/Cl24RE & ACE & Prelingual & Congenital \\
4 & 45 & F & Bilateral & Right & 37 & 4 & Nucleus/Cl512 & ACE & Postlingual & Unknown \\
5 & 45 & F & Bilateral & Right & 38 & 10 & Nucleus/Cl24RE & SPEAK & Postlingual & Unknown \\
6 & 54 & M & Bilateral & Left & 15 & 4 & Med El/Opus 2 & FSP & Postlingual Meniere's Disease \\
7 & 59 & M & Bilateral & Right & 11 & 1 & Nucleus/Cl24RE & ACE & Postlingual & Noise induced \\
8 & 63 & F & Bilateral & Right & 35 & 3 & Nucleus/CI512 & ACE & Postlingual & Genetic \\
9 & 69 & M & Bilateral & Left & 22 & 2 & Med El/Opus 2 & FSP & Postlingual & Genetic \\
10 & 74 & M & Unilateral & Left & 12 & 5 & Nucleus/Cl24RE & ACE & Postlingual & Unknown \\
\hline
\end{tabular}

Cl: cochlear implant 
Table 2. Summary of the different types of speech perception scores for the $\mathrm{Cl}$ users

\begin{tabular}{|c|c|c|c|c|c|c|c|c|c|}
\hline $\mathrm{Cl}$ user & & Sentence & Word ${ }_{\text {total }}$ & Word ${ }_{\text {high }}$ & Wordiow & Consonant & Vowel & $\begin{array}{c}\text { Composite } \\
\text { Score }\end{array}$ & Study group \\
\hline \multirow[t]{2}{*}{1} & $Q$ & 24 & 67 & 68 & 40 & 85 & 32 & 52 & Poor \\
\hline & $\mathrm{N}$ & 10 & 42 & 20 & 24 & 45 & 35 & 33 & \\
\hline \multirow[t]{2}{*}{2} & $Q$ & 8 & 33 & 28 & 4 & 42 & 55 & 34 & Poor \\
\hline & $\mathrm{N}$ & 4 & 30 & 12 & 4 & 50 & 53 & 34 & \\
\hline \multirow[t]{2}{*}{3} & $Q$ & 4 & 30 & 32 & 16 & 30 & 30 & 23 & Poor \\
\hline & $\mathrm{N}$ & 0 & 20 & 16 & 8 & 25 & 33 & 19 & \\
\hline \multirow[t]{2}{*}{4} & $Q$ & 28 & 64 & 72 & 48 & 74 & 75 & 50 & Poor \\
\hline & $\mathrm{N}$ & 2 & 9 & 16 & 4 & 37 & 50 & 24 & \\
\hline \multirow[t]{2}{*}{5} & $Q$ & 46 & 80 & 84 & 24 & 84 & 70 & 70 & Good \\
\hline & $\mathrm{N}$ & 30 & 70 & 60 & 24 & 74 & 57 & 58 & \\
\hline \multirow[t]{2}{*}{6} & $Q$ & 74 & 94 & 96 & 68 & 90 & 90 & 87 & Good \\
\hline & $\mathrm{N}$ & 40 & 77 & 88 & 16 & 71 & 80 & 67 & \\
\hline \multirow[t]{2}{*}{7} & $Q$ & 82 & 96 & 96 & 76 & 85 & 82 & 86 & Good \\
\hline & $\mathrm{N}$ & 28 & 73 & 72 & 52 & 66 & 60 & 57 & \\
\hline \multirow[t]{2}{*}{8} & $Q$ & 74 & 93 & 100 & 72 & 76 & 80 & 81 & Good \\
\hline & $\mathrm{N}$ & 40 & 73 & 84 & 40 & 48 & 65 & 56 & \\
\hline \multirow[t]{2}{*}{9} & $Q$ & 48 & 81 & 92 & 44 & 80 & 63 & 68 & Good \\
\hline & $\mathrm{N}$ & 28 & 62 & 72 & 20 & 69 & 68 & 56 & \\
\hline \multirow[t]{2}{*}{10} & $Q$ & 76 & 94 & 100 & 88 & 94 & 73 & 84 & Good \\
\hline & $\mathrm{N}$ & 46 & 82 & 84 & 72 & 62 & 58 & 62 & \\
\hline \multirow[t]{2}{*}{ Good } & $Q$ & 67 & 90 & 95 & 62 & 85 & 76 & 79 & - \\
\hline & $\mathrm{N}$ & 35 & 73 & 77 & 37 & 65 & 65 & 59 & \\
\hline \multirow[t]{2}{*}{ Poor } & $Q$ & 16 & 49 & 50 & 27 & 58 & 48 & 40 & - \\
\hline & $\mathrm{N}$ & 4 & 25 & 16 & 10 & 39 & 43 & 28 & \\
\hline \multirow[t]{2}{*}{ All } & $Q$ & 46 & 73 & 77 & 48 & 74 & 65 & 60 & - \\
\hline & $\mathrm{N}$ & 23 & 54 & 52 & 26 & 55 & 56 & 44 & \\
\hline $\mathrm{NH}$ & - & - & - & - & - & - & - & - & - \\
\hline
\end{tabular}

The last column represents subgroups of $\mathrm{Cl}$ users. Q: quiet, $\mathrm{N}$ : noise, $\mathrm{Cl}$ : cochlear implant, $\mathrm{NH}$ : normal hearing

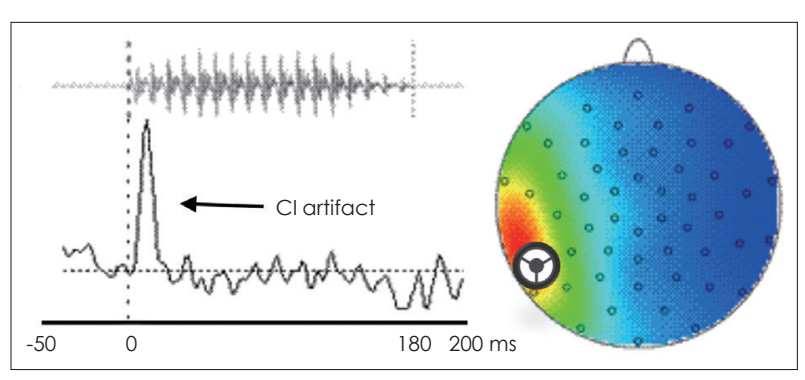

Fig. 1. The example of $\mathrm{Cl}$ artifact in respond to /ba/ stimulus. The features of $\mathrm{Cl}$ artifact are instantaneous waves with the onset of sound increased energy near $\mathrm{Cl}$ peak topography. The VOT of sound waveform in this figure is $0 \mathrm{~ms}$. Note that the $\mathrm{Cl}$ is located at a left ear. $\mathrm{Cl}$ : cochlear implant, VOT: voice onset time.

abram/index.html). Fig. 1은 본 연구에서 사용된 $0 \mathrm{~ms}$ VOT 의 파형과 자극음에 따른 인공와우 잡음(artifact)과 토포그 래피(topography)를 보여준다. 모든 자극음은 VOT 구간을 포함하고, 입술에 의한 파열 구간을 지나 모음 / / /로 끝나는 형식으로 구성되었으며, 자극음의 총 지속시간은 $180 \mathrm{~ms}$ 으 로 모두 동일하게 유지하였다. 자극음은 직접 제작한
Matlab(MathWorks, Natick, MA, USA)를 이용하여 Tucker-Davis Technologies(TDT, Alachua, FL, USA) 사의 RZ5 를 통해 호환 가능한 디지털 사운드 파일로 변환하여 전달되 었고, 동시에 TDT를 통해 신호가 전달되는 시간을 실시간으 로 컴퓨터에 저장하였다. Bruel and Kjær 2260 사운드 레벨 미터(Bruel and Kjær, Nærum, Denmark)를 사용하여 소 리의 강도를 보정하였다.

\section{연구 절차}

\section{뇌파 측정}

뇌파는 64채널 뇌파측정기(actiChamp; Brain Products $\mathrm{GmbH}$, Munich, Germany)를 이용하여, 전극이 부착된 캡 을 두피에 씨워 측정하였다. 접지 전극은 비근점(미간; nasion)과 $\mathrm{Cz}$ 위치의 중간 지점에 위치하도록 조절하였으며 총 64개 중 한 개는 기준 전극으로 $\mathrm{Cz}$ 에 위치하였고, 나머지 63 개의 전극에서 뇌파를 측정하였다. 본 연구에서는 등거리 레 
이아웃이 적용된 전극 캡을 사용하였는데, 이 캡은 international 10-20 시스템을 따르지 않기 때문에 $\mathrm{Cz}$ 의 위치에 가 장 가까운 3 개의 전극에서 얻어진 뇌파의 값을 평균하여 $\mathrm{N} 1$ 을 측정하였다. 자극음은 피험자로부터 $1.5 \mathrm{~m}$ 앞 정면에 위 치한 스피커를 통해 쾌적강도레벨(most comfortable level, $\mathrm{MCL}$ ) 수준의 크기로 차폐 방음실 안에서 제시되었다. 자극 음 사이 구간(inter-stimulus interval, ISI)은 1.5 초로서 자 극음이 끝난 후 1.5 초의 휴지 구간을 지나 그다음 자극음이 제시되었다. 모든 인공와우 사용자는 왼쪽 혹은 오른쪽 귀 중 청력 역치가 더 낮은 한쪽 귀에만 인공와우를 착용한 상 태로 청각 유발 전위 측정을 실시하였다. 정상 청력 대조군 은 스피커를 통해 양쪽 귀로 소리를 전달받았으며, $70 \mathrm{~dB}$ 의 강도로 자극음을 제시하였다. 실험 시 피험자는 자신이 선택 한 음소거 된 영화를 시청하였으며, 이해를 위해 자막을 제 시하였다. 집중에 의한 하향식 처리(top-down processing) 의 영향을 최소화할 수 있도록 실험을 시작하기에 앞서 피험 자에게 영화에 최대한 집중하고, 자극음은 무시하도록 지시 하였다. 각 VOT 자극음 당 200회씩 총 1200회(6 VOTs $\times$ 200회)의 자극음이 정상 청력군에게 제시되었고, 인공와우 사용자군의 경우 인공와우에 의한 잡음(noise)이 많이 발생 하므로, 자극음 당 최소 400회씩 총 2400회(6 VOTs $\times 400$ 회) 의 자극음이 4 개의 블록에 걸쳐 제시되었다. 뇌파 측정 후 Polhemus Patriot 3D 디지타이저(Polhemus, Colchester, $\mathrm{VT}, \mathrm{USA}$ )를 이용하여 각 피험자의 정확한 전극 위치를 기 록하였으며, 이는 쌍극자 분석에 사용되었다. 데이터 저장 시 표본율(sampling rate)은 $1000 \mathrm{~Hz}$ 였고 모든 데이터는 오프 라인 분석을 위해 저장되었다. 모든 자극음은 예측 효과를 방지하기 위해 무작위 순서로 제시되었으며, 총 뇌파 측정 시 간은 정상 청력인의 경우 평균 1.5 시간, 인공와우 사용자는 평균 2.5 시간이 소요되었고, 각 세션 사이와 피험자가 원하 는 때에 휴식 시간이 주어졌다.

\section{뇌파의 전처리 및 기록}

뇌파의 전처리(preprocessing) 및 분석은 Brain Vision Analyzer 2.0(Brain Products $\mathrm{GmbH}$ )을 사용하여 실시되었 다. 측정된 뇌파는 먼저 고대역 통과 필터(high-pass filter) 를 사용하여 저주파에서 발생하는 잡음 신호를 제거하기 위 해 $0.01 \mathrm{~Hz}$ 이하 주파수를 차단하였고, 표본율을 $512 \mathrm{~Hz}$ 로 낮추었다. 또한, 통과 주파수 대역 필터링(band-pass filter) 을 이용하여 전원에 의해 발생하는 잡음 $(60 \mathrm{~Hz})$ 을 차단하였 다. 이후 육안검사(visual inspection)로 신체 움직임과 관련 된 잡음을 제거하였고, 독립성분분석(independent component analysis, ICA)을 통해 눈 깜빡임/좌우 움직임, 심전도 (electrocardiography), 인공와우 잡음(CI artifact)을 제거하 였다. Fig. 1 에 자극음의 제시에 따른 인공와우 잡음이 나타 난 파형과 토포그래피에 나타나는 인공와우 관련 대뇌 활동 성에 대한 대표적인 예시를 제시하였다.

잡음 제거(artifact rejection)가 완료된 데이터는 저대역 통 과 필터(low-pass filter)로 $20 \mathrm{~Hz}$ 이상의 주파수를 필터링하 였고, 자극 시작점인 $0 \mathrm{~ms}$ 를 기준으로 자극 전 $200 \mathrm{~ms}$ 에서 부터 자극 후 $1000 \mathrm{~ms}$ 까지 총 $1200 \mathrm{~ms}$ 으로 분할(segmentation)하여 분석에 활용하였다. 6 가지의 VOTs 조건에 따라 나누어진 데이터는 조건당 실시된 시행 수를 63 개의 전극 별 로 평균화하여 기준 전극의 평균값으로 빼주었다.

\section{뇌파 신호원 분석(EEG source analysis)}

쌍극자 신호원 분석(dipole source analysis)은 $\mathrm{BESA} \mathrm{Re}-$ search 6.0(Brain Electric Source Analysis, $\mathrm{GmbH}$ )을 사용 했으며, Hine과 Debener ${ }^{17)}$ 의 논문에서 설명한 것과 유사한 방법으로 분석을 실시하였다. 이 논문에서는 등가 쌍극자 모 델(equivalent dipole model)을 적용하여 왼쪽과 오른쪽 반 구에 각각 한 개의 대칭적인 위치에 쌍극자를 심어 쌍극자의 위치와 방향을 계산하는 방식을 이용하였다. 양쪽 반구의 쌍 극자들은 청각 자극에 가장 민감하게 반응하는 것으로 알려 진 횡회(Heschl's gyrus, centroid, in Talairch 좌표: \pm 49.5 , $-17,9)$ 근방에 배치하였다. 위치 설정을 위한 Talairch 좌표 는 Hine과 Debener ${ }^{17)}$ 의 연구에서 적용한 좌표를 이용하였 다. N1의 전부위장력(global field power; GFP)을 측정하여 최대 진폭을 포함한 $20 \mathrm{~ms}$ 구간의 데이터를 쌍극자 분석에 사용하였으며, 쌍극자 중에서도 접선(tangential) 신호원을 $\mathrm{N} 1$ 쌍극자 분석에 활용하였다. 쌍극자들에 의해 발생하는 각 전극 채널의 전위 측정치의 오차를 최소화하기 위해 모든 피험자에서 $20 \mathrm{~ms}$ 구간을 기준으로 측정한 적합도(goodness of fit, GOF)가 $80 \%$ 이상이 되는 데이터만 최종 분석에 사용 되었다. 마지막으로 모든 피험자에서 평균 쌍극자 파형(grand mean source waveform)을 계산하였으며, 조건 간의 통계적 차이를 평가하기 위해, 접선 쌍극자의 피크를 중심으로 한 $20 \mathrm{~ms}$ 구간에서의 평균값이 통계 분석에 사용되었다.

인공와우 사용자군(poor vs. good CI performers)의 반구 상 비대칭을 비교하기 위해 편재화 지수(lateralization in$\mathrm{dex})$ 를 다음의 식을 이용하여 계산하였다.

편재화 지수(lateralization index)

$=($ contralateral-ipsilateral $) /($ contralateral+ipsilateral $)$

편재화 지수는 -1 부터 +1 까지 분포하며, + 는 대측 반구로 의 편측성을 의미하고, - 는 동측으로의 편측성을 의미한다. 


\section{통계 방법}

통계 분석은 Statistica SPSS version 12(SPSS Inc., Chicago, IL, USA) 프로그램을 이용하여 실시되었다. 독립변수 는 6개의 VOT 값과 피험자 그룹이었으며, 종속변수로는 x, $\mathrm{y}, \mathrm{z}$ 쌍극자 위치와, 쌍극자 신호원 활동성이 설정되었는데, 쌍극자 활동성의 경우 인공와우 사용자는 동측과 반대측의 대뇌 활동성이, 정상 청력군은 오른쪽과 왼쪽 대뇌 활동성이 사용되었다. 반복측정 분산분석(repeated measures analysis of variance)이 그룹 내 변수(6개의 VOT)와 그룹 간 변수 (우수 $\mathrm{CI}$ 군, 저조 $\mathrm{CI}$ 군, 정상청력군)에 따른 $\mathrm{N} 1$ 쌍극자 활동 성에서의 유의미한 차이가 있는지, 또한 변수 간 상호작용 (interaction)이 있는지 조사하였으며, 유의미한 차이가 있는 경우 Fisher's Least Significant Difference(LSD)를 통해 사후 검증을 실시하였다. N1 쌍극자 위치는 $\mathrm{x}, \mathrm{y}, \mathrm{z}$ 각각의 위치에 서의 인공와우 사용자군과 정상 청력군과의 차이를 독립표 본 t 검정을 통해 검증하였다. 인공와우 사용자군에서의 편 측 지수와 말지각력과의 상관관계는 스피어만 상관계수 (Spearman's rank correlation coefficient)를 이용하여 검증 하였다.

\section{결 과}

\section{$\mathrm{N} 1$ 쌍극자 위치}

쌍극자 분석 결과 정상 청력 대조군과 인공와우 사용자군 모두에서 $80 \%$ 이상의 적합도를 나타내었다. Fig. 2는 VOT 에 따른 정방향과 역방향의 평균 쌍극자 신호원 파형을 보여 주고 있다. 전체적으로 VOT가 증가할수록 N1 쌍극자 반응 이 작아지는 현상이 관찰되었으며, 정상 대조군과 우수 인공 와우 사용자군에 비해 저조 인공와우 사용자군에서 N1 신 호원 활동성이 감소된 것으로 나타났다.

쌍극자 위치 분석 결과, 쌍극자 핏(dipole fit)이 일차 청각 영역(primary auditory cortex)과 그 주변에 위치한 것을 확 인할 수 있었다. VOT의 변화에 따른 쌍극자 위치 변화를 통 계적으로 분석한 결과 유의미한 VOT 효과는 관찰되지 않았 다 $(p>0.05)$. 그룹 간 비교를 위해 우수 인공와우 사용자 군 과 저조 인공와우 사용자 군의 쌍극자 위치를 비교한 결과 전후 방향(anterior-posterior direction; y)에서 $40 \mathrm{~ms}$ 의 $\mathrm{VOT}$ 가 자극음으로 주어졌을 때 두 인공와우 그룹 간의 유 의미한 차이가 관찰되었다 $(\mathrm{t}=-2.62, \mathrm{df}=18, p<0.05)$.

\section{$\mathrm{N} 1$ 쌍극자 파형 패턴과 반구상 비대칭성}

Fig. 3은 우수 인공와우 사용자군과 저조 사용자군에서의 $\mathrm{VOT}$ 의 변화에 따른 동측과 반대측의 쌍극자 신호원 파형의
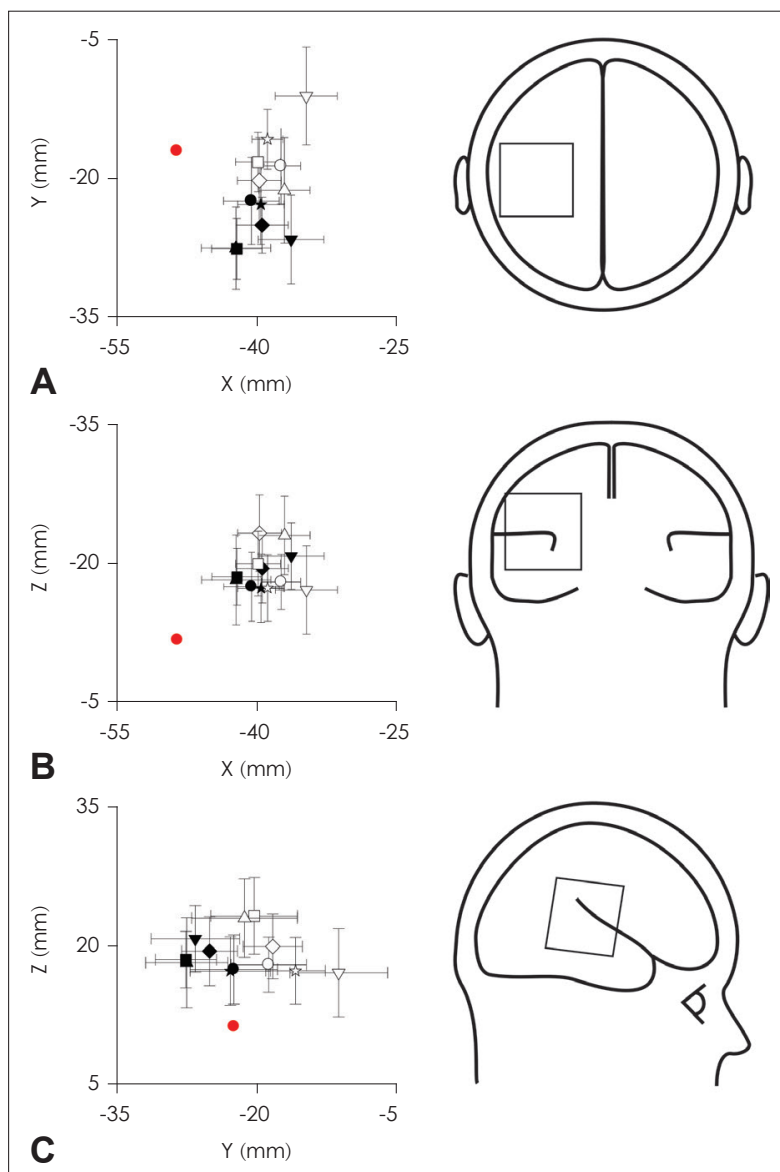

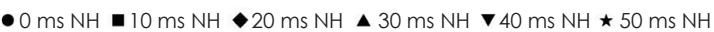
$\circ 0 \mathrm{msCl} \square 10 \mathrm{msCl} \diamond 20 \mathrm{msCl} \triangle 30 \mathrm{msCl} \nabla 40 \mathrm{msCl} \star 50 \mathrm{msCl}$

Fig. 2. N1 dipole locations for each of six VOTs in $\mathrm{Cl}$ and $\mathrm{NH}$ groups. The dipoles are shown at the location of best fit in each of three views; transverse (A), coronal (B), and sagittal (C). For the $\mathrm{Cl}$ group, individual dipoles are shown for contralateral and ipsilateral activity. Dipole fits for the NH group represent the left and the right auditory cortex. Red dots indicate Heschl's gyrus (Talairch coordinates: $\pm 49.5,-17,9)$. Cl: cochlear implant, NH: normal hearing, VOT: voice onset time.

평균(grand mean average)과, 정상 청력군의 왼쪽과 오른쪽 반구 그랜드 평균 신호원 파형을 보여주고 있다.

Fig. 3에서 보이는 바와 같이, 전체적인 N1 쌍극자 파형의 패턴은 모든 VOTs 조건에서 우수 인공와우 사용자군의 동 측과 대측 $\mathrm{N} 1$ 활동성 모두 저조 사용자 군에 비해 높고, 정 상군보다는 낮은 것으로 나타났다. 또한 VOT 길이에 따른 $\mathrm{N} 1$ 쌍극자 활동성의 편재화 지수의 변화를 Fig. 4에 제시하 였다. 전체적인 패턴을 살펴보았을 때, 우수 인공와우 사용자 군에서는 모든 $\mathrm{VOT}$ 조건에서 대측의 활동성이 큰 것으로 나타났으나, 저조 군에서는 20 30 ms VOT를 제외하고 나머 지 VOT에서는 동측 방향으로 활동성이 증가한 것으로 나타 났다.

$\mathrm{VOT}$ 길이에 따른 N1 쌍극자 진폭과 잠재기의 변화를 알 


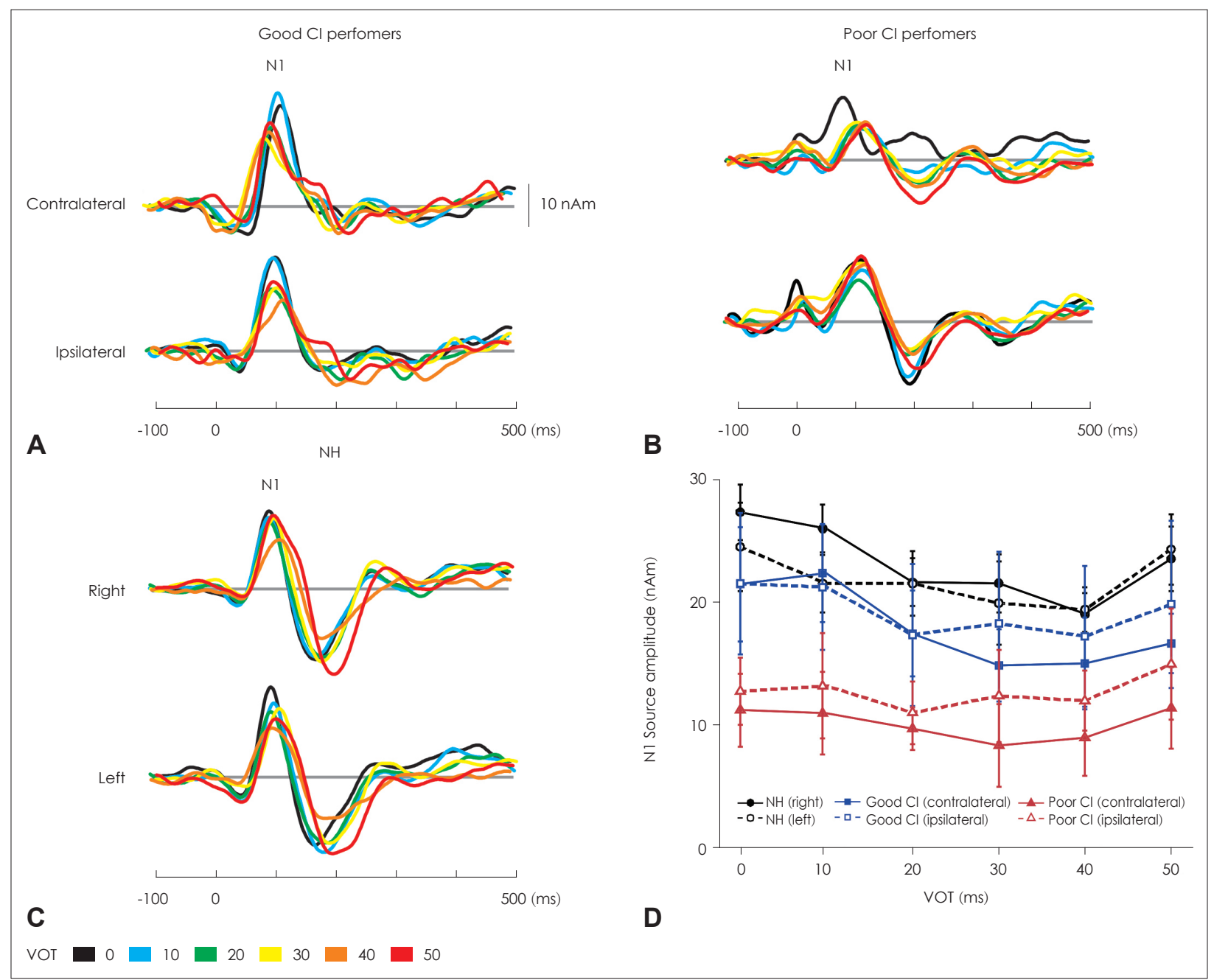

Fig. 3. Dipole source waveforms as a function of VOT. Individual waveforms represent contralateral and ipsilateral activity for Good $\mathrm{Cl}$ performers (A), Poor Cl performers (B) and $\mathrm{NH}(\mathrm{C})$ right and left auditory activity are shown. N1 source amplitude as a function of VOT (D). Black circles, blue squares, and red triangles represent $\mathrm{NH}$, good $\mathrm{Cl}$, and poor $\mathrm{Cl}$ groups, respectively. $\mathrm{Cl}$ : cochlear implant, $\mathrm{NH}$ : normal hearing, VOT: voice onset time.

아보기 위해 반복 측정 분산분석을 이용하여 그룹 간(우수 인공와우/저조 인공와우/정상대조군) 비교와 그룹 내(VOT 의 길이: 0 50 ms) 비교를 실시하였다. N1 쌍극자 진폭과 잠 재기는 피험자가 착용한 인공와우 기준으로 동측과 대측의 진폭과 잠재기를 각각 측정하였으며, 정상 청력군의 경우 왼 쪽과 오른쪽 반구의 N1 쌍극자 진폭과 잠재기를 측정하여 반구상 비대칭을 분석하였다. 통계 분석 결과 그룹 간 차이 는 통계적 유의성에 근접하나 유의미하게 나타나지는 않았 다 $[\mathrm{F}(2,17)=3.01, p=0.07]$. 하지만 사후 검증 분석 결과 우수 인공와우군과 저조 인공와우군을 비교했을 때, 대측에서의 $\mathrm{N} 1$ 쌍극자 진폭이 유의미하게 증가한 것으로 나타났다 $(p<$ 0.05). 또한 $\mathrm{VOT}$ 효과 $[\mathrm{F}(5,40)=4.05, p<0.05]$ 와 $\mathrm{VOT}$ 와 그룹 간 상호작용 $[\mathrm{F}(5,40)=2.59, p<0.05]$ 효과 모두 통계적으로 유 의미하게 나타났다. 사후 검증 분석 결과, 우수 인공와우군

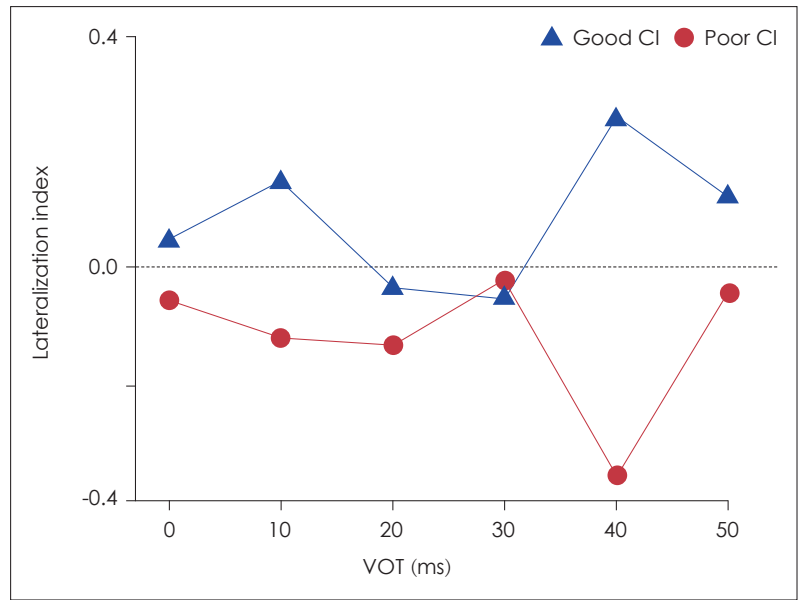

Fig. 4. Lateralization index as a function of VOT in good and poor $\mathrm{Cl}$ groups. Note that a plus (+) in lateralization index means the contralateral dominance while a minus (-) indicates the ipsilateral dominance. $\mathrm{Cl}$ : cochlear implant, VOT: voice onset time. 
의 $\mathrm{N} 1$ 쌍극자 진폭이 $0 \mathrm{~ms}$ 과 $10 \mathrm{~ms}$ VOT보다 $20,30,40$, $50 \mathrm{~ms} \mathrm{VOT}$ 에서 유의미하게 감소한 것으로 나타났다(all $p<$ 0.05). N1 잠재기에서도 유의미한 VOT 효과가 관찰되었으며 $[\mathrm{F}(5,40)=3.5, p<0.05], 50 \mathrm{~ms}$ VOT에서의 동측 쌍극자의 잠 재기가 $10 \mathrm{~ms} \mathrm{VOT}$ 보다 유의미하게 증가된 것으로 나타났 다 $(p<0.05)$.

\section{$\mathrm{N} 1$ 쌍극자 활동성과 말지각력 간의 상관관계}

인공와우 사용자의 N1 쌍극자 활동성의 반구상 비대칭성 이 그들의 말지각 능력과 상관관계가 있는지 알아보기 위하 여 $20 \mathrm{~ms}$ VOT에서의 N1 쌍극자 편재화 지수와 소음 하 자 음 지각 검사에서의 수행력과의 상관관계를 분석하였다. Fig. 5는 인공와우 사용자들의 소음 하 자음 지각 점수에 따 른 편재화 지수를 나타내고 있다. 스피어만 상관계수 분석 결과 인공와우 사용자군의 편재화 지수가 소음 하 자음 지 각력과 통계적으로 유의미한 상관관계를 보이는 것으로 나 타났으며(spearman's rho=0.71, $p<0.05$ ), 이는 소음 하 자음 지각력이 좋을수록 대측 반구에서의 $\mathrm{N} 1$ 쌍극자 활동성이 증가하는 것을 의미하며, 이와 반대로 지각력이 낮을수록 동 측인 반구에서의 $\mathrm{N} 1$ 활동성이 커지는 것을 의미한다.

\section{고 찰}

본 연구는 인공와우 사용으로 인한 대뇌 가소성을 쌍극자 신호원 분석을 통해 알아보고, 측정된 대뇌 활동성의 특성과 인공와우 이식 후 말지각력과의 상관관계를 밝히고자 하였 다. 연구 결과, 말지각력이 우수한 인공와우 사용자군은 대

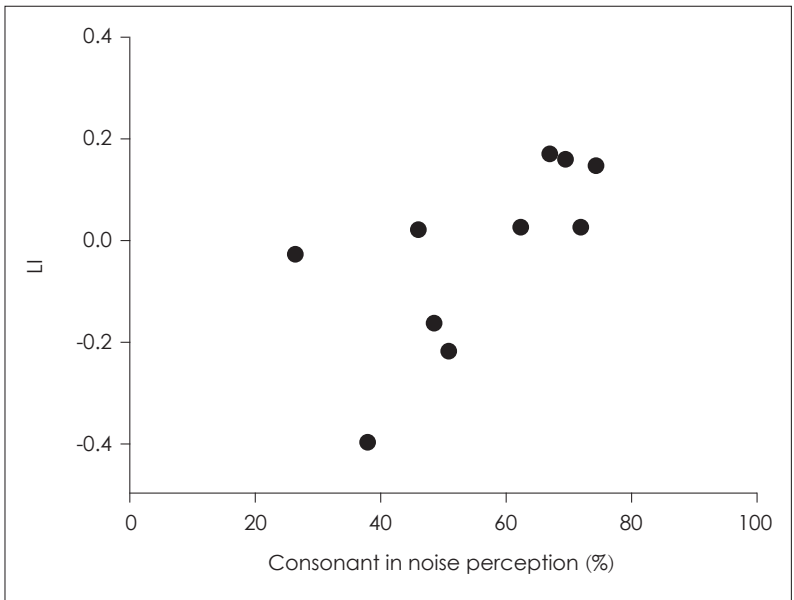

Fig. 5. Relationship between LI for N1 dipole source amplitudes and consonant in noise perception in $\mathrm{Cl}$ users. The Lls for $\mathrm{N} 1 \mathrm{di}-$ pole source amplitude at $20 \mathrm{~ms}$ VOT were positively related to consonant in noise scores in $\mathrm{Cl}$ users $(r=0.71, p<0.05)$. Cl: cochlear implant, LI: lateralization index.
측 반구에서 $\mathrm{N1}$ 쌍극자 활동성이 증가한 것으로 나타났으 나, 말지각력이 저조한 인공와우 사용자군은 이와 반대로 동 측 반구에서 활동성이 높게 나타났다. 또한 인공와우 사용자 의 N1 쌍극자 활동성에 대한 편재화 지수가 소음 하 자음 지 각력과 관련성이 깊은 것으로 나타났다.

\section{$\mathrm{N} 1$ 쌍극자 신호원의 위치}

그룹 간 N1 쌍극자의 위치를 비교하였을 때 우수 인공와 우 사용자군의 N1 쌍극자의 위치는 저조 인공와우 사용자 군의 쌍극자의 위치와 전후 방향에서(Fig. 2) 유의미한 차이 를 보인 반면, 정상 청력군과의 차이는 나타나지 않았다. 이 는 우수군과 저조군의 인공와우 이식 후 대뇌 재조직화 패턴 이 상이한 것을 의미한다. 인공와우 사용자를 대상으로 뇌자 도를 이용하여 N1 쌍극자 위치를 비교한 선행연구에 따르 면, 인공와우 이식 후 2년이 지난 피험자의 $\mathrm{N} 1 \mathrm{~m}$ 신호원 위치 와 정상 대조군에서 측정한 $\mathrm{N} 1 \mathrm{~m}$ 신호원의 위치가 차이가 없 었다고 보고하였다. ${ }^{18)}$ 한편, 인공와우 환자의 대뇌 재조직화 연구에서는 N1 쌍극자가 대뇌 피질의 어느 부위에 위치하는 지가 중요하다고 주장하였다. 정상 청력인에서 측정된 $\mathrm{N} 1$ 쌍 극자의 위치는 일차 청각 피질뿐만 아니라 연합 청각 피질과 같은 비일차 청각 대뇌피질 부위(non-primary auditory cortex)를 포함하는 것으로 알려져 있는데, ${ }^{19)}$ 인공와우 사용 자를 대상으로 한 연구에서도 N1 쌍극자 신호원이 비일차 청각 피질 부위에 위치하는 것을 확인하였다. ${ }^{20)}$ 따라서 인공 와우를 통한 청각 자극의 재유입은 정상적인 패턴으로의 대 뇌 대조직화를 야기한다고 볼 수 있으며, 이러한 재조직화는 말지각력이 좋은 인공와우 사용자에게 더욱 현저히 나타나 는 것으로 생각된다.

\section{$\mathrm{N} 1$ 쌍극자 신호원 활동성과 반구성 비대칭}

본 연구에서는 인공와우 사용자의 반구성 비대칭의 패턴 이 말지각 수준에 따라 상이하다는 것을 확인하였다. 우수 인공와우 사용자의 경우 인공와우의 이식 방향을 기준으로 대측에서 $\mathrm{N} 1$ 활동성이 더 증가한 것으로 나타났으나, 저조 인공와우 사용자군에서의 $\mathrm{N} 1$ 활동성은 동측에서 더 큰 것 으로 관찰되었다. 인공와우 사용자의 반구상 비대칭에 대한 선행연구를 살펴보면 상반되는 결과를 제시하고 있다. ${ }^{18} \mathrm{~F}-$ FDG-PET을 이용하여 반구상 비대칭을 살펴 본 연구에서 는 자극 제시 방향과 상관없이 오른쪽 반구에서 대뇌 활동 성이 더 크게 나타났다고 보고하였으나," 성인 ${ }^{17}$ 과 아동 ${ }^{21)}$ 인 공와우 사용자의 경우 왼쪽 귀로 자극음을 제시하였을 경우 에만 반대쪽 반구의 우세가 더 두드러진다고 보고하였다. 이 러한 상이한 결과를 야기한 이유 중 하나는 여러 연구에서 
서로 다른 자극 제시 방향과 분석 방법을 사용했기 때문으 로 생각된다. 하지만 최근 들어 인공와우를 착용한 귀를 기 준으로 대측과 동측의 대뇌 활동성을 분석하는 방법을 많이 사용하고 있고, 이러한 방법을 적용한 연구들은 비교적 일관 적인 연구 결과를 보고하고 있다. 그중에서도 인공와우를 착 용한 아동을 대상으로 한 연구에서 흥미로운 연구 결과들이 발표되었다. Gilley 등 ${ }^{8}$ 은 단음절 말소리를 이용하여 P1 쌍 극자 연구를 시행하였는데, 인공와우 이식 시기와 관계없이 모든 아동에서 동측과 비교하여 더 큰 대측 $\mathrm{P} 1$ 활동성이 확 인되었다. 편측성 인공와우 아동을 대상으로 한 연구에서도 대측 쌍극자 활동성이 증가한 것으로 나타났다. 하지만 남은 한쪽 귀에 인공와우를 이식한 후에는 이전에 보였던 대측의 활동성이 우세했던 현상이 현저히 줄어들거나, 비대칭성이 사라져 대뇌 전반에 걸친 쌍극자 활동성이 관찰되었다.,5,21) 또 다른 연구에서는 양측 인공와우 이식 아동을 대상으로 $\mathrm{P} 1$ 활동성을 측정하였는데, 양측 인공와우 이식 아동에게 정상 청력 아동에서 나타나는 대측 반구 우세가 나타내었으 며, 대측 반구의 활동성이 클수록 높은 말지각력을 나타내었 다.) 이러한 선행연구의 결과와 유사하게, 본 연구에서도 말 지각력이 우수한 인공와우 사용자에서 대측 활동성이 높게 나타났는데, 이와 같은 현상은 유입된 자극음을 효율적으로 처리하기 위해 대측 청각 피질로 정보를 보내기 위한 대뇌의 책략이며, ${ }^{22)}$ 이러한 대뇌 처리 경로로 정보전달이 가능한 인 공와우 사용자들의 말지각력이 더 우수한 것으로 유추된다. 반면에 말지각력이 저조한 사용자의 경우는 청각 피질을 포 함한 청각 중추에서는 정보의 정확한 처리가 어렵기 때문에, 양쪽 반구를 동시에 사용하거나 대뇌 전반에 걸친 신경 활 동을 유도하는 것으로 추측된다. 혹은 인공와우의 부적응 (maladaptation)으로 인한 비정상적인 대뇌 재조직화의 결과 로, 정상적인 청각 처리 경로를 벗어나서 다른 경로를 이용하 는 것으로도 추측할 수 있다. ${ }^{5)}$

\section{뇌 활동성과 말지각력의 상관관계}

본 연구에서는 인공와우 사용자에서 나타난 반구상 비대 칭이 행동적으로 측정한 말지각 능력과 연관이 있는지 살펴 보기 위하여 편재화 지수와 소음 하 자음 지각 점수와의 상 관관계를 살펴보았다. 여러 말지각 검사 중 소음 하 자음을 선택한 이유는 선행연구에서 다른 종류(모음, 단어, 문장 등) 의 말지각 검사보다 자음, 특히 소음 하에서의 말지각 능력이 대뇌 활동성과 연관이 깊은 것으로 나타났기 때문이다. ${ }^{23,24)}$ 본 연구에서는 심리음향학적으로 가장 변별이 어려운 $20 \mathrm{~ms}$ $\mathrm{VOT}$ 에서의 N1 쌍극자 편재화 지수가 소음 하 자음 지각력 과 유의미한 상관관계를 보였는데, 이는 성인 인공와우 사용
자의 반구상 비대칭과 말지각력 간의 유의미한 상관관계를 보고한 이전 연구의 결과와 유사하다. ${ }^{25)}$ 인공와우 사용자는 클릭 같은 단순 자극음보다 말소리와 같은 복합음의 처리가 어려우며, 복합음의 효과적인 처리를 위해 가장 효율적인 대 뇌 처리 경로를 개발하는 방향으로 대뇌 재조직화가 실행되 는 것으로 알려져 있다. ${ }^{26)}$ 이러한 하향 조절(top-down modulation) 능력이 더 좋은 사용자일수록 시간적 정보를 처리 하는 청각 경로가 특화되어 더 우수한 말지각력으로 나타나 는 것으로 유추된다.

이전의 많은 선행연구에서 청성 뇌간 반응, 복합신경 활동 전위 등의 다양한 객관적 측정 도구와 행동적으로 측정한 인공와우 사용자의 말지각력 간의 상관관계를 조사하였으 나, 두 측정치 간의 유의미한 상관관계를 발견하지 못하였 다. ${ }^{27-29)}$ 인공와우 이식 후 이식자의 말지각 능력은 매우 다양 하게 나타나지만 아직도 그 원인은 밝혀지지 않은 상태이다. 또한 주관적 검사가 어려운 피검자나 영유아의 경우 행동적 으로 측정하는 방식의 적용은 임상적으로 어렵기 때문에 대 뇌 피질 유발 전위와 같은 객관적 측정도구의 개발이 시급한 실정이다. 따라서 N1 대뇌 유발 전위를 이용하여 이식 후의 인공와우의 이득에 대한 평가가 가능하다면 임상적으로 큰 도움이 될 수 있을 것이다. 하지만 임상적 적용을 위해서는 다양한 연령의 인공와우 사용자를 대상으로 한 연구가 진행 되어야 할 것이며, 영유아를 위해 실험 시간을 단축하여 측 정할 수 있는 연구 방법이 개발되어야 할 것이다.

결론적으로, 본 연구는 성인 인공와우 사용자에서 시간 정보를 포함한 말소리 자극에 따른 대뇌 활동성의 변화를 쌍극자 신호원 분석을 통해 알아보았다. 연구 결과 인공와우 사용자의 N1 쌍극자의 반구상 비대칭이 언어적 수행력과 연 관성이 있는 것으로 나타났다. 연구 결과의 확장과 임상적 적 용을 위하여 후속 연구에서는 더 많은 표본수의 인공와우 사용자를 대상으로 연구가 실시되어야 할 것이다. 또한 인공 와우 적응 기간에 따른 대뇌 활동성의 변화를 종단 연구를 통해 알아본다면 인공와우 사용자의 대뇌 재조직화에 대한 이해를 높이고, 최적화된 청각 재활 모델을 개발하는 데 이 론적인 도움이 될 것으로 사료된다.

\section{Acknowledgments}

This project was supported in part by Basic Science Research Program through the National Research Foundation of Korea (NRF) funded by the Ministry of Education (2019R1A2B5B01070129 and 2017R1D1A1B03030613) and by the Center for Women in Science, Engineering and Technology (WISET) Grant funded by the Ministry of Science, ICT \& Future Planning of Korea (MSIP) under the Program for Returners into R\&D (WISET-2019-252). 


\section{ORCID}

Hyo-Jeong Lee https://orcid.org/0000-0003-2258-0803

\section{REFERENCES}

1) Giraud AL, Price CJ, Graham JM, Frackowiak RS. Functional plasticity of language-related brain areas after cochlear implantation. Brain 2001;124(Pt 7):1307-16.

2) Debener S, Hine J, Bleeck S, Eyles J. Source localization of auditory evoked potentials after cochlear implantation. Psychophysiology 2008;45(1):20-4.

3) Pantev C, Ross B, Berg P, Elbert T, Rockstroh B. Study of the human auditory cortices using a whole-head magnetometer: Left vs. right hemisphere and ipsilateral vs. contralateral stimulation. Audiol Neurootol 1998;3(2-3):183-90.

4) Gordon KA, Wong DDE, Papsin BC. Bilateral input protects the cortex from unilaterally-driven reorganization in children who are deaf. Brain 2013;136(Pt 5):1609-25.

5) Jiwani S, Papsin BC, Gordon KA. Early unilateral cochlear implantation promotes mature cortical asymmetries in adolescents who are deaf. Hum Brain Mapp 2016;37(1):135-52.

6) Lazard DS, Lee HJ, Truy E, Giraud AL. Bilateral reorganization of posterior temporal cortices in post-lingual deafness and its relation to cochlear implant outcome. Hum Brain Mapp 2013;34(5):1208-19.

7) Kang E, Lee DS, Lee JS, Kang H, Hwang CH, Oh SH, et al. Developmental hemispheric asymmetry of interregional metabolic correlation of the auditory cortex in deaf subjects. Neuroimage 2003;19(3):777-83.

8) Gilley PM, Sharma A, Dorman MF. Cortical reorganization in children with cochlear implants. Brain Res 2008;1239:56-65.

9) Doucet ME, Bergeron F, Lassonde M, Ferron P, Lepore F. Crossmodal reorganization and speech perception in cochlear implant users. Brain 2006;129(Pt 12):3376-83.

10) Hauthal N, Sandmann P, Debener S, Thome JD. Visual movement perception in deaf and hearing individuals. Adv Cogn Psychol 2013;9(2):53-61.

11) Picton TW. Human auditory evoked potential. 1st ed. San Diego, CA: Plural Publishing Inc;2011. p.1-634.

12) Wolpaw JR, Wood CC. Scalp distribution of human auditory evoked potentials. I. Evaluation of reference electrode sites. Electroencephalogr Clin Neurophysiol 1982;54(1):15-24.

13) Dimitrijevic A, Pratt H, Starr A. Auditory cortical activity in normal hearing subjects to consonant vowels presented in quiet and in noise. Clin Neurophysiol 2013;124(6):1204-15.

14) Sharma A, Dorman MF. Cortical auditory evoked potential correlates of categorical perception of voice-onset time. J Acoust Soc Am 1999;106(2):1078-83.

15) Iverson P. Evaluating the function of phonetic perceptual phenomena within speech recognition: An examination of the perception of / d/-/t/ by adult cochlear implant users. J Acoust Soc Am 2003;113 (2):1056-64.

16) Park JH, Han JH. Behavioral perception and neural correlates of categorical perception in cochlear implant users. Korean J Otorhinolaryngol-Head Neck Surg 2018;61(1):15-23.

17) Hine J, Debener S. Late auditory evoked potentials asymmetry revisited. Clin Neurophysiol 2007;118(6):1274-85.

18) Pantev C, Dinnesen A, Ross B, Wollbrink A, Knief A. Dynamics of auditory plasticity after cochlear implantation: A longitudinal study. Cereb Cortex 2006;16(1):31-6.

19) Pantev C, Bertrand O, Eulitz C, Verkindt $C$, Hampson S, Schuierer $\mathrm{G}$, et al. Specific tonotopic organizations of different areas of the human auditory cortex revealed by simultaneous magnetic and electric recordings. Electroencephalogr Clin Neurophysiol 1995; 94(1):26-40.

20) Sharma A, Gilley PM, Dorman MF, Baldwin R. Deprivationinduced cortical reorganization in children with cochlear implants. Int J Audiol 2007;46(9):494-9.

21) Yamazaki H, Easwar V, Polonenko MJ, Jiwani S, Wong DDE, Papsin BC, et al. Cortical hemispheric asymmetries are present at young ages and further develop into adolescence. Hum Brain Mapp 2018;39(2):941-54.

22) Kral A, Sharma A. Developmental neuroplasticity after cochlear implantation. Trends Neurosci 2012;35(2):111-22.

23) Han JH, Zhang F, Kadis DS, Houston LM, Samy RN, Smith ML, et al. Auditory cortical activity to different voice onset times in cochlear implant users. Clin Neurophysiol 2016;127(2):1603-17.

24) Kelly AS, Purdy SC, Thorne PR. Electrophysiological and speech perception measures of auditory processing in experienced adult cochlear implant users. Clin Neurophysiol 2005;116(6):1235-46.

25) Sandmann P, Eichele T, Buechler M, Debener S, Jäncke L, Dillier $\mathrm{N}$, et al. Evaluation of evoked potentials to dyadic tones after cochlear implantation. Brain 2009;132(Pt 7):1967-79.

26) Kral A, Eggermont JJ. What's to lose and what's to learn: Development under auditory deprivation, cochlear implants and limits of cortical plasticity. Brain Res Rev 2007;56(1):259-69.

27) Abbas PJ, Brown CJ. Electrically evoked auditory brainstem response: Refractory properties and strength-duration functions. Hear Res 1991;51(1):139-47.

28) Hirschfelder A, Gräbel S, Olze H. Electrically evoked amplitude modulation following response in cochlear implant candidates: Comparison with auditory nerve response telemetry, subjective electrical stimulation, and speech perception. Otol Neurotol 2012; 33(6):968-75.

29) Lundin K, Stillesjö F, Rask-Andersen H. Prognostic value of electrically evoked auditory brainstem responses in cochlear implantation. Cochlear Implants Int 2015;16(5):254-61. 